Cómo citar este artículo en APA: Paris, Y. (2022).

Perpetrator Trauma as a Possible Solution

for Cultural Trauma:

The Case of Joshua

Oppenheimer's The Act of Killing (2012) and The Look of Silence (2014).

Analecta Política, 12(22), 1-26. doi: http://dx.doi. org/10.18566/apolit. v12n22.a02

Fecha de recepción: 07.09.2021

\section{Perpetrator Trauma as a Possible Solution for Cultural Trauma: The Case of Joshua Oppenheimer's The Act of Killing (2012) \\ and The Look of Silence \\ (2014)}

El trauma del perpetrador como una posible solución al trauma cultural: El caso de The Act of Killing (2012) y The Look of Silence (2014), de Joshua Oppenheimer

\section{YAGO PARIS}

Ph.D. Candidate, Doctorate Program of Humanities: Language and Culture Universidad Rey Juan Carlos - MadridResearch Group in Visual Arts and Cultural Studies (GIAVEC) https://orcid.org/0000-0002-3003-6675 yagoparis89@gmail.com 


\section{Abstract}

The present article analyzes Joshua Oppenheimer's documentaries The Act of Killing (2012) and The Look of Silence (2014) from the perspective of trauma. The aim of this study is to give new approaches that could allow a deeper understanding of such a complex sociopolitical situation as the one that is taking place in nowadays Indonesia. First, I will introduce the term cultural trauma to explain the situation of the victims of the 1965-66 mass killings that took place in Indonesia. Then, I will make use of the concept of the political taboo to better understand how the official narrative imposed by the government has worked, and still works, as some sort of unquestionable myth. Afterward, I will point out that these two concepts give birth to a vicious cycle from which escaping becomes highly unlikely. A possible solution I propose here comes from studying another type of trauma, that of the perpetrator, since, in an indirect way, it can lead to an improvement of cultural trauma. By approaching trauma in a non-moralistic sense, allowing the perpetrator the status of a victim, I intend to highlight the importance of empathy and understanding in the process of healing of not only perpetrator trauma, but also, and more importantly, cultural trauma.

Keywords: trauma, cultural trauma, perpetrator trauma, documentary, Indonesia

\section{Resumen}

El siguiente artículo analiza los documentales The Act of Killing (2012) y The Look of Silence (2014), de Joshua Oppenheimer, desde el punto de vista del trauma. El objetivo de este estudio consiste en ofrecer nuevas aproximaciones que puedan permitir un entendimiento más profundo de una situación sociopolítica tan compleja como la que tiene lugar hoy en día en Indonesia. Primero, presentaré el término "trauma cultural», para explicar la situación de las víctimas de las matanzas de 1965-66 que tuvieron lugar en Indonesia. Posteriormente, utilizaré el concepto "tabú político» para entender mejor cómo la narrativa oficial impuesta por el gobierno ha funcionado, y continúa haciéndolo, como una especie de mito incuestionable. A continuación, señalaré que estos dos conceptos dan lugar a un círculo vicioso del que escapar es altamente improbable. En este punto propongo como una posible solución el estudio de otro tipo de trauma, el del perpetrador, puesto que, de una manera indirecta, puede dar lugar a una mejora del trauma cultural. Mediante 
una aproximación no moralista al concepto de trauma, una en la que se le concede al perpetrador un estatus de víctima, pretendo poner de manifiesto la importancia de la empatía y el entendimiento en el proceso de curación, no solo del trauma del perpetrador, sino, además, y aún más importante, del trauma cultural.

Palabras clave: trauma, trauma cultural, trauma del perpetrador, documental, Indonesia

\section{Perpetrator Trauma as a Possible Solution for Cultural Trauma: The Case of Joshua Oppenheimer's The Act of Killing (2012) and The Look of Silence (2014)}

At the beginning of The Act of Killing (Joshua Oppenheimer, 2012), a set of titles explain to the audience the context of present-day Indonesia, as a result of events of its recent past:

In 1965, the Indonesian government was overthrown by the military. Anybody opposed to the military dictatorship could be accused of being a communist: union members, landless farmers, intellectuals, and the ethnic Chinese. In less than a year, and with the direct aid of western governments, over one million "communists" were murdered. The army used paramilitaries and gangsters to carry out the killings. These men have been in power -and have persecuted their opponents- ever since.

A very similar message appears at the beginning of The Look of Silence (Joshua Oppenheimer, 2014). With this very short contextualization, director Joshua Oppenheimer sets the ground for his double effort to tackle the very conflictive sociopolitical situation in Indonesia. In the first film, he exposes the vision of the past from the perspective of the perpetrators, whereas in the second one, he gives voice to the victims of the mass killings. With these two documentaries, the filmmaker attempts to shed light on this situation, in order to better understand the blockage that the Indonesian society is suffering in terms of human rights.

This paper seeks to continue the work initiated by Oppenheimer, but with the attempt to widen the perspective on the situation, partially by questioning some of the decisions and moralistic visions offered by the films. First, I intend 
to offer a possible explanation of the very impacting scenes that appear in both documentaries. In order to do that, I will first introduce the term "cultural trauma", which will help me better explain the situation of the victims. Afterward, I will introduce the term "political taboo", one which will clarify the reasons for having created such an inflexible official narrative of the past, one which does not allow any type of criticism or alternative vision of it. One of the key goals of this essay is to highlight the fact that these two concepts are interconnected: the perpetrators, whose actions led to the development of cultural trauma in the other social group, created a narrative reinforced by political taboos, and by doing so, they prevent cultural trauma from healing. This enhances the negative repercussions of cultural trauma over the victims, and the reinforcement of cultural trauma provokes an even higher need to apply the political taboo, in order to maintain the status quo. In other words, this is a vicious cycle in which both sides reinforce each other.

After having explored this situation, I will develop a study on the behavioral traits of the perpetrators, in order to find key aspects that would lead to a possible improvement of the situation. More concretely, I will explore the concept of "perpetrator trauma", one that usually receives little attention, but which can actually be the key to improving this conflict. Through the analysis of Anwar Congo's behavior, one of the perpetrators and the protagonist of The Act of Killing, I will propose the phenomenon of "witness traumatization" as the key point of his partial dramatic arc of acknowledging the Other as a victim of his actions. At the same time, I will explore the reasons why perpetrators are not usually allowed the status of victims of the traumatic events, and will propose a non-moralistic approach to trauma to improve the healing of perpetrator trauma, which will indirectly help in the healing of their victims' trauma. In conclusion, after having explored the situation from many different angles, proposing ideas and concepts to better understand the reasons behind such a problematic sociopolitical context, I will propose approaching trauma in a different sense, one in which empathy and understanding, and not moralistic judgment, can be the key to an actual improvement of conflictive situations.

\section{The Unsolved Cultural Trauma}

Following Cathy Caruth's (see 1995) psychoanalytical approach, trauma can be defined as the consequences of having suffered an overwhelming experience. One of the most useful therapeutic approaches to healing trauma consists of the victim telling their experience to the Other. This Other is normally a psychologist 
or a psychiatrist, but, in the end, it could be anyone willing to listen. The idea is that when somebody listens to the testimony of a victim, this person is attending the victim's departure from the event, in order to break the isolation that the event imposes (Caruth, 1995, p. 11). The role of the listener is fundamental for treatment, up to the point that the testimony includes the listener, who becomes some kind of "blank screen on which the event comes to be inscribed for the first time" (Laub, 1992, p. 57).

Having this in mind, the depiction of the situation that the victims of the Indonesian genocide have to confront already goes against recovery, since, due to their fear of speaking about the past, the trauma cannot be fully healed. As opposed to the perpetrators, who talk about their experiences with an impressive amount of detail and with a tone that goes from the need to tell their story to pure pride, the main trait of the victims' behavior is their unwillingness to talk. This can be explained mainly as a result of fear, because, even the ones who dare face the camera and tell their story still do it in a very different manner. In these cases, the audience will not find a set of details or passionate speeches. On the contrary, victims speak scarcely, since they are still in pain, and remembering becomes a strong confrontation for them. There is a sequence in The Look of Silence that highlights this difference. The fragment of the documentary exposes the remembrance of the crimes that took place in a certain area of the country. First, the perpetrators' point of view is illustrated, and afterward comes the one from one of the victims, a man who was able to escape the mass murder. In the first case, there is a highly detailed, frivolous narration of the actions, even with reenactments of the killings. In the second, silence dominates the scene. The narration of the victim is short and does not offer many details, and there is the constant reminder of the lives lost in the area, up to the point that the victim directly addresses their souls and asks for forgiveness for being there, disrupting their rest. As a result, and due to the past and present sociopolitical context, the victims have to face a psychological barrier that prevents them from actually healing from their trauma.

Nevertheless, in the case of communities, ethnicities, or even whole nations, the previously exposed psychoanalytical perspective of trauma is not enough to understand the situation; it is necessary to confront the issue from a different perspective, one which includes the cultural aspect of the collective. In those cases, it is necessary to address the concept of cultural trauma. According to Jeffrey C. Alexander's social theory of trauma, cultural trauma takes place when people who belong to a social group have the feeling that they have suffered a shocking, unforgettable experience which changes their awareness of themselves 
as a collective. Complementary to it is Ron Eyerman's definition, in which cultural trauma is considered as "a dramatic loss of identity and meaning, a tear in the social fabric, affecting a group of people that has achieved some degree of cohesion" (2004, p. 61). In both definitions, the notion of the collective is paramount. This is explained by the idea that, in such cases, these groups of people identify with the traumatic experience that others inside of this community suffered, up to the point that they can even take responsibility for it (Alexander, 2004, p. 1). These different conceptions of trauma -the one offered by Caruth and the one by Alexander and Eyerman himself- have been signaled by Ron Eyerman (see 2019a). According to this author, the psychoanalytic approach offers "the naturalistic assumption that trauma is the direct result of [...] a wound [...] visited on the mind through an overwhelming experience," whereas cultural trauma "is more contingent and involves discursive practices, collectivities, collective memory, and collective identity in a struggle to define what is experienced as traumatic" (Eyerman, 2019a, p. 145-46). The latter approach is the one that will receive more attention throughout this paper.

Taking Alexander's previous quote, trauma is shared by the community, as it can be seen in one of the last scenes of The Look of Silence, in which the mother of Adi, the protagonist, meets the survivor introduced before in this text. When they meet, the mother instantly starts to cry, and both melt in a hug without the need to express anything through verbal communication, because the mutual understanding allowed by the same trauma creates a context of shared suffering, which connects with the emphasis that Eyerman puts on collective memory and identity formation (see 2004, 2019a). Another crucial aspect of cultural trauma is the fact that, even though some individuals might not have suffered the traumatic experience, they are in fact traumatized by the event itself, as they identify with other members of the community (Alexander, 2004, p. 1). This can be observed in the case of Adi, who is traumatized by the murder of his elder brother, even though he was not even born by the time this happened -as it is explained in the documentary, Adi was born two years after this event-. In other words, Adi does not even have memories of the mass murders, let alone of his brother, and yet he has developed a trauma due to the sharing quality of cultural trauma, in which "members of collectivities define their solidary relationships in ways that, in principle, allow them to share the sufferings of others." (Alexander, 2004, p. 1). Cultural trauma is, thus, shared among the members of the community, through the construction of shared collective memory, and, as a result, it is necessary to deal with it, so that the new generations belonging to this social group can avoid the traumatic identification. 
As it has been pointed out, trauma is healed through talking. The victim starts departing from their trauma by sharing their story, which means that another person has to listen to what they have to say. Listening is a form of acknowledging what happened, and doing it legitimizes the suffering of the victim, which is recognized as such. In cultural trauma, where the most likely scenario is that a social group acts in a way that provokes trauma over another social group, the idea of legitimization scales to the public sphere. In these cases, State recognition of these collectives as victims is a necessary step for proper trauma healing. Nevertheless, many times the social group in power is the one who has inflicted trauma, normally as a way to achieve such power. This is the case of the Indonesian genocide. By 1965, the Partai Komunis Indonesia (PKI) was ruling the country, when a military coup took place. The same anti-communist group has remained in power ever since -even after the death of dictator Suharto-, since the hypothetical democracy that came afterward has been anything but democratic. As it is exposed in both documentaries, the press is controlled by the government, and the perpetrators of mass murders, who are gangsters and members of paramilitary groups, can openly talk about what they did, since there is total impunity for their actions. As a result, the sociopolitical situation in Indonesia is far from encouraging a public debate about the recent past of the country. One of the main reasons for this is that the victims themselves are afraid of talking, since, as they know who controls the power in their nation, speaking out will most likely mean suffering the consequences, which, as it is exposed in the documentaries, can escalate to the level of murder. In The Act of Killing, the actions of some artists and activists are addressed, and it is explained that one of them was kidnapped and has never come back, which is interpreted as an almost certain murder.

But besides the actual brutal force that can be applied to the ones who dare question the regime, the case requires a deeper study in order to fully understand the complexity of the situation. At this point, it is fundamental to address the attitude of the perpetrators. Injustice and genocide are, unfortunately, not unusual. Nevertheless, the most striking aspect of these two documentaries is the behavior of the perpetrators, a fact that becomes the core of The Act of Killing. Even when killers are openly considered as such, they are expected to act by avoiding to talk about it, or pretending they had nothing to do with the mass murders.

This is not the case in Indonesia, where the killers openly talk about what they did, with a mixture of ignorance of the repercussions of their actions and an actual pride toward it. This is the attitude shown by the protagonists of 
The Act of Killing. Anwar Congo, Herman Koto, and Adi Zulkadry act in a similar manner, a type of behavior that can be understood through the logic of the political taboo. This concept can be defined as a set of ideas created by the ruling class to control the collective consciousness of a concrete topic that directly affects the development of a social group's awareness of itself. These ideas are unquestionable in the public sphere and become some kind of "mystified and sanctified words," resulting in the lack of any kind of criticism toward the past (Blanuša, 2017, p. 171). This official discourse, which could be understood as propaganda, creates a fixed, unquestionable version of the past, one in which the rulers become heroes and the members of the other social group are portrayed as enemies of the State, dehumanized to the point that violence and murder are justified and even celebrated.

With this in mind, it is easier to understand what could bring people like Anwar Congo to openly talk about how he killed other members of society, who had been accused of being communists, and more concretely, how he can speak in a frivolous, sometimes even humorous, manner about the methods utilized to perpetrate such assassinations. The perpetrators can behave in such a way because their actions have been justified and glorified by the official discourse, and given form through the logic of the political taboo, which prevents any questioning of the official version of the past.

When the logic of the political taboo is applied to cultural trauma, it can provoke the refusal of a collective to recognize the other's suffering. In this case, the perpetrators do not want to recognize the victims as such, since they consider this social group as an enemy of the State. This is crucial when the collective who refuses to recognize it is, precisely, the direct responsible for the creation of such trauma. In those cases, the perpetrators do not want to recognize the victims as such, also because that would mean recognizing that what they did was wrong. Political taboo applied to the Other's cultural trauma often comes along with the idea of victimization. The collective which has caused the trauma not only does not recognize it, but also feels that, actually, the traumatized group is the cause of all its problems and sufferings. In this case, the perpetrators feel that they were victims of the communists, and, as a result, their actions were deemed needed. This way, their terrible actions are justified and glorified as an act of defense of themselves and their country. In summary, the political taboo not only does not help in solving cultural trauma, but also leaves the traumatized to suffer alone (Alexander, 2004, p. 1). In other words, the political taboo can play a crucial role in the impossibility to heal cultural trauma. 
In order to prevent the political taboo from being questioned by the members of its own community, there are certain defenses prepared to avoid this from ever happening. According to the theory exposed by Antoon Van den Braembussche (1998, pp. 106-110), there are four different types of taboo's defense mechanisms. The first one could be defined as a conscious denial of what differs from the explanation of the past. Throughout The Look of Silence, every time Adi tries to speak about the past with the different perpetrators he meets, a similar pattern takes place. In the beginning, the questions are not harsh or confrontational, and, as a result, the perpetrators feel comfortable explaining what they remember about the past. This changes when Adi brings up topics that connect to ideas of guilt or responsibility. In these cases, every interviewee reacts in a similar manner, by rejecting the version of the past that Adi offers. There is a fixed idea of the past, and any diversion is immediately canceled. In the interview with Inong, the leader of a village's death squad, he justifies the killings of the members of the Communist Party by arguing that they had no religion, and that they would sleep with each other's wives. When Adi answers that these were only rumors, he exclaims " $t \mathrm{t}$ hey said it themselves! When we interrogated them." There is a fixed, immobile vision of the past which does not allow any discrepancy.

The second defense mechanism might be defined as a reinterpretation of historical events to delegitimize historical undeniable facts. The best example of this can be found in the NBC newsreel filmed in the country shortly after the coup had taken place, and it is included in The Look of Silence. In it, a journalist is interviewing a Balinese person, who explains why the massacre had taken place:

-Journalist: "Bali is such a beautiful island. People are so attractive, the climate is so lovely. It's hard to believe that so many unpleasant things went on here over the last year."

-Balinese: "Yeah, but now Bali has become more beautiful without communists."

-Journalist: "What actually happened here, in this village?"

-Balinese: "Some of the communist leaders from this village realized they were wrong, and they came to the village council and asked when the village council will clean the village of communist people."

-Journalist: "You mean the communists themselves asked to be killed?"

-Balinese: "Some of them. Some of them wanted to be killed. 'Now give me a chance to say goodbye to my relatives, and the next morning I'm ready to be killed."” 
By building up a new narrative -even when it is a very hard to believe one-, the perpetrators delegitimize any possible alternative explanation of the past, even when there is proof that the official version is false. This can only happen due to the third type of defense mechanism, which consists of the creation of myths or legends, to justify historical facts. Political meetings take place during The Act of Killing, and one of them is the one that The Pancasila Youth organizes. This far-right paramilitary organization had a leading role during the 1965-66 massacre, and they have perpetuated the official narrative of the State ever since. One of its higher rank members is Yapto Soerjosoemarno, who gives a speech at this gathering: "All Pancasila Youth members are heroes," because they exterminated the communists, fought the neo-communists and left-wing extremists, and any enemy of the State. He claims that " $[t]$ his isn't only the duty of the army and police," and that, as a result, this organization had to take a stand. It is not only remarkable the way in which he describes the political situation and the justification of mass murder, but also the fact that he is not only speaking about the past, but about the present situation, too. Altogether, this mythical description of the Pancasila Youth members, portrayed as heroes who helped and continue to help in saving the nation, prevents any selfcriticism about their actions.

The fourth defense mechanism consists of the unconscious repression of memory to avoid the instability of the identity. This can be observed, in a general sense, with any of the interviewees, since all of them offer a similar pattern of denial of certain actions and repetition of similar ideas which belong to the official discourse. They do this in order to justify their actions so that their formed identity will not be questioned and that their fragile sense of inner peace is not threatened. It is also remarkable to discover these patterns among the people who belong to this social group, but who had not taken direct action in the massacres themselves. This can be observed in a scene from The Look of Silence where Adi visits the family of one of the perpetrators, Amir Hasan. The initial idea was to interview him, but, since he had passed away by the time the documentary was being developed, the film crew decided to organize a meeting with his widow and his sons. Before witnessing this conversation, the audience has had access to footage of an interview with Hasan, along with Inong. In these images, we can see Hasan accompanied by his wife. The most remarkable aspect about this footage which was filmed during the development of The Act of Killing but in the end was not included in the documentary- is the presence of a book written by Hasan, so that his story, the testimony of what happened, will survive his death. This book, where-as it happens with the rest of the perpetrators that appear in both documentaries-their responsibility in the murders is not only not hidden, but 
openly celebrated, is the undeniable proof that Hasan was responsible for the death of 32 people. Even Joshua Oppenheimer received a copy of this book, that Hasan proudly gave to him. This copy reappears in the cited scene in The Look of Silence, where Adi meets Hasan's family. Besides the expectable rejection that all the members of the family express toward Adi's alternative testimony, the crucial situation that can best explain this fourth defense mechanism is the fact that Hasan's widow claims that she was unaware of the existence of this book, despite the fact that the audience has previously seen her in the cited footage, directly engaging with it. This suppression of certain memories and facts is, thus, necessary in order to ensure the official discourse's survival.

In a general sense, in order to better understand why these defense mechanisms are applied, it could be argued that an important aspect of the idea of identity is based on the need to create a strong differentiation between the Self and the Other. "The individual identifies with the specific myths of a nation's enjoyment, which structure everyday beliefs and practices of the group" (Krstic, 2002, p. 10). Consequently, hatred toward the Other's enjoyment is created as a result of this group feeling that the Other is trying to steal the enjoyment that belongs to the former, which is the basis of this collective's existence. Promoting hate and lack of empathy toward the Other, who needs to be dehumanized and understood as a threat, is a way of enforcing the definition of the Self. This can clearly be observed in the double scene in The Look of Silence, where the audience witnesses how the official discourse is explained to children at school by teachers:

"Communists are cruel. Communists don't believe in God. To change the political system, the Communists kidnapped six army generals. They sliced the generals' faces with razor blades. [...] The Communists were cruel, so the government had to repress them. The Communists were put in prison. Their children couldn't become government officials, [...] if you rebel against the State, you go to jail. So let's thank the heroes, who struggle to make our country a democracy."

Afterward, one of the students, who happens to be Adi's son, tells him what he was taught. The conversation evolves as it follows:

-Son: "The generals refused to sign, so their faces were cut with razors. Their eyes were gouged out. Another general refused to sign, so they sliced his cheek. When he still refused, they gouged his eyes."

-Adi: "According to your teacher, who killed the generals?"

-Son: "The killers."

-Adi: "Didn't he say it was the Communists?" 
-Son: "Yes."

-Adi: "It's all lies. All this talk about gouging eyes..."

-Son: "So the communists weren't cruel?"

-Adi: "No, they weren't."

-Son: "I was told they were cruel."

-Adi: "The generals were killed by the army, not by the Communists. Did your teacher mention the people killed at Snake River? Or the million innocent people who were murdered? No."

In this double scene, we can find the different defense mechanisms that help in preventing the questioning of the political taboo. By offering a fixed, inflexible version of the past, there is a conscious denial of alternative explanations. At the same time, historical facts, such as the actions of the communists, are reinterpreted in order to delegitimize those historical undeniable facts. At the same time, the State is portrayed in a mythical sense, as the saviors of the nation, which is only acceptable if the people involved in creating or perpetuating it allow unconscious repression of memories that would question this national identity that has been created. So, in the end, the four taboo's defense mechanisms help to create a hegemonic ideology that silences the traumatized Other and prevents the Self from dealing with its own past and responsibility in the generation of such cultural trauma. In other words, as I have claimed at the beginning of this chapter, the political taboo prevents cultural trauma from healing.

\section{Perpetrator Trauma}

As Saira Mohamed highlights in her paper (see 2015), the approach that director Joshua Oppenheimer takes for the development of The Act of Killing, that is, giving the perpetrators space to tell their story and, in a sense, offering a more humanized depiction of them, provoked rejection in some sectors of film criticism. Nevertheless, as she claims in her essay, the first thing we must acknowledge is the fact that "a cultural evolution in the concept of trauma from a psychological category to a moral one" has taken place, and, as a result, she considers that "a counternarrative of trauma-one that recognizes trauma as a neutral, human trait, divorced from morality, and not incompatible with choice and agency" must be developed (2015, p. 1157), in order to "restore trauma as a category with no predetermined moral status" (2015, p. 1208). Bernhard Giesen agrees with this perspective when he claims that "[p]erpetrators are human subjects who, by their own decision, dehumanized other subjects and, in doing so, did not only 
pervert the sovereign subjectivity of the victims but challenged also their own sacredness" (2004, p. 114). He further argues that, since the Other's recognition is fundamental for one's self-consciousness, "it is exactly this recognition that is denied to the perpetrators (cp. Hegel's famous dialectics of recognition, Hegel 1927, 148ff)." (2004, p. 114). This approach, Giesen and Mohamed share, would already help in relating with the Other in a more fair sense, but the latter takes this argument even further when she later claims that this approach would not only be beneficial in terms of reintegration of the perpetrator into society, but could also help in actually solving the conflictive situation between perpetrators and victims in social contexts such as the Indonesian one, because "[t]hose who are traumatized are less likely to have empathy for others, and more likely to continue to 'devalue and blame' victims" (Mohamed, 2015, p. 1204). In other words, helping the Indonesian perpetrators heal from their trauma can actually help in solving the sociopolitical situation of the Indonesian victims, and thus help in healing their cultural trauma.

As Bernhard Giesen claims, "constructions of national identity cannot escape from an orientation toward the past, which does not pass away, whether traumatic or triumphant. Traumas and triumphs constitute the 'mythomoteurs' of national identity (Barthes 1996)" (2004, p. 112). This can apply to cases where different social groups of the same nation have different narratives of the past. In the case of the Indonesian society, there is a group that has a triumphant narrative -the official discourse of the perpetrators, which gives birth to the political taboo that helps maintain it-, whereas another has a traumatic one -the cultural trauma of the victims-. In both cases, the past -Eyerman's sense of collective memory (or memories, in this case)- marks the projection of the identity toward the future, and, even though the narrative might be a triumphant one, this does not necessarily imply that traumatic happenings were absent from the events that gave birth to the later triumphant narrative. In both cases, "[ $t$ hese myths represent the unique founding moment by familiar patterns and turn the unspeakable experience into a story that can be communicated" (Giesen, 2004, p. 113). In other words, events are turned into narratives, and, as a result, an interpretation, or manipulation, of the past can be applied in order to make an understanding of the events possible, one in which unacceptable events might be transformed into acceptable ones. In short, "a struggle over meaning" (Eyerman, 2019a, p. 145) takes place, and, even though the author used this expression to describe the process of cultural trauma, the description also fits the construction of the perpetrators' narrative that influences the collective memory of the group and the subsequent identity formation of each individual belonging to it. This identity construction can help to better understand two aspects of the perpetrator: on the one hand, how is it possible 
that they can cope with terrible events that they have directly or indirectly been involved with, and, precisely because of that, how is it possible that, even though they belong to the triumphant narrative, they might be suffering from trauma.

As Giesen himself explains, using Cathy Caruth's psychoanalytic approach, " $t \mathrm{t}$ ] raumas remember a moment of violent intrusion or conversion that the consciousness was not able to perceive or to grasp in its full importance when it happened" (2004, p. 113). In the case of the social group to which the perpetrators belong, "collective consciousness tends to reject perceiving the actions of its own community as barbaric in the moment when the barbaric violence occurs" (Giesen, 2004, p. 116). This happens because, in these cases, the members of this community would need to acknowledge that some of its members are not the heroes that the narrative of the community claims they are, but, on the contrary, have become "perpetrators who violated the cultural premises of their own identity," and that, as a result, "the reference to the past is indeed traumatic" (Giesen, 2004, p. 114).

In such psychological circumstances, or, from the perspective of the social theory of trauma, in such a struggle for meaning, the way the members of this community can deal with "the fundamental contradiction between identity claims and recognition [is] only by a collective schizophrenia, by denial, by decoupling or withdrawal" (Giesen, 2004, p. 114). In that sense, Eyerman offers a complementary vision of the process, in which atrocities would be possible through peer pressure, the presence of a commanding authority, a preservation instinct, and the dehumanization of the Other (2019b, 176-77). Having all of this in mind, understanding the attitudes of the Indonesian social group to which the perpetrators belong is easier to understand, as it will be further analyzed with specific examples. At this point, we can propose an explanation as to how the killers have been able to normalize their terrible actions, and why the people surrounding them have chosen to erase certain memories or think of those actions as necessary ones. Nevertheless, trauma might still be present, but simply blurred in the mass of elisions and justifications. This is the case of the perpetrators that appear in The Act of Killing.

Throughout the film, we can see different people having a certain need to tell their story, regardless of how atrocious it is. This attitude can be explained from different angles. As it was exposed in The Look of Silence with the case of the perpetrator who decided to write a book about his story, or in the case of the protagonists of The Act of Killing, who decide to shoot an amateur film to narrate their past, there is a need for recognition, which is a normal behavior in 
any social being. At the same time, the intense need for constant retelling feels odd, as if something else was missing. This something else, I claim, is the need for healing the trauma of the perpetrator. The continuous remembrance of the past can happen because the events have not received closure. This is manifested with special intensity in the case of Anwar Congo, who, as Lúcia Nagib argues (see 2016), suffers from post-traumatic stress disorder (PTSD), which is the traumatic response of the individual to the traumatic event. Cathy Caruth describes the consequences of this syndrome as "repeated, intrusive hallucinations, dreams, thoughts or behaviors stemming from the event, along with numbing that may have begun during or after the experience, and possibly also increased arousal to (and avoidance of) stimuli recalling the event" (1995, p. 4).

From the perspective of the social theory of trauma, Eyerman (2019b) argues that perpetrator trauma can appear when both individuals and collectives act against their moral beliefs. Since these beliefs are "so foundational", the consequences can be that "one's identity and self-esteem can feel as though they have been shattered, a sense that gives rise to a strong emotional response including feelings of guilt and remorse," that could lead to suffering pathological symptoms (Eyerman, 2019b, p. 167-68). In the case of Anwar, this repetitive pattern of thoughts and dreams -nightmares, actually-impel him to the reenactments of the past events, both for the documentary and the amateur film. Even though PTSD normally appears sometime after the event itself, it is the first time that the victim has real knowledge of the experience. Being shocked by the happening, the victim does not really register it in their memory when it takes place. As a result, a void is created in the mind, with which the mind itself tries to deal later, by trying to understand what is impossible to understand, what goes beyond symbolization. This is why, when PTSD starts, the dreams and hallucinations are not based on repressions or desires, but on literality. The repetitive visions of the victim are fragments of memory that the mind recovers in an attempt to understand what happened, so, in the end, trauma can be defined as the collapse of the understanding of an overwhelming experience (Caruth, 1995, p. 7). This constant repetition of memories and thoughts that Anwar Congo experiences is an attempt of his mind to try to understand what took place in the past and was against his moral beliefs, in this case, a set of events which can also be atrocious for the person who actively perpetrated them.

Lúcia Nagib analyzes Congo's behavior as the result of the symptom called "presentification," which consists of the impression that the past traumatic event is still taking place in the present (2016, p. 229). Another sensation that is common in PTSD and that is present in one of the most impressive scenes of the 
documentary is nausea. The interpretation that Nagib offers to the situation that Anwar Congo is experimenting is that he is attempting to "bring back the dead to the present time in their material reality, through his own body, including a harrowing scene of the actor's unpredictable and uncontrollable retching as he reenacts the killing of his victims through strangulation" (2016, p. 219). Mohamed offers a different interpretation, one which suggests that a collapse in linear time is taking place, as a result of "the past resurfacing as a vivid present." In other words, it would not be the impression of the past event still taking place in the present, but rather the "inability to distinguish present time from the time of the traumatic wound." Since Congo has never healed from his own trauma, it has "never been properly consigned to the past," and, as a result, the memories attached to it reappear in the present time (Mohamed, 2015, pp. 1195-96). In both interpretations, the result would be the same: the reenactment as a desperate solution to try to properly deal with the traumatic past events, in a terrifyingly painful struggle for meaning. As a result, even though we could interpret the development of the amateur film as a frivolous approach to the past, with which the political taboo of the official version given by the authorities is reinforced, a more likely interpretation would be that of seeing this project as a desperate attempt to seal the wound of the traumatized perpetrator.

Another aspect of trauma which could help in delving deeper into this case is the one that manifests in one of the rehearsals of the amateur film, in which Anwar Congo is not actually performing the role of a perpetrator -his real role in the past-, but that of the victim -the Other's role-. As a result, he is able to experience, through a performative act, the feelings that his victims suffered. This event causes a tremendous impression on him. He even needs to stop the performance. I interpret this experience as a manifestation of the so-called "witness traumatization." This is normally described as a process that can happen when the listener of the traumatized person becomes traumatized by the testimony, through a logic of identification and empathy. If we take the perspective expressed by Caruth, we can think of trauma as some kind of contagion that is spread by language and representation. If we think of trauma as not attached to the event and its witnesses, the possibility that the Other's testimonies are able to traumatize the listener is related to the idea of trauma traveling "across histories and cultures to resonate within the very structures of our being" (Caruth, 1995, p. 10).

Congo's performance could be understood as a variation of witness traumatization, one which would be even more effective in that sense, since the reenactment is a much more intense experience than the listening of a story. This scene of the documentary is crucial to understand the evolution of the character 
-or, at least, this is the narrative that Oppenheimer appears to have wanted to offer, through the mise-en-scène, editing, and scriptwriting processes-. Before this event, Anwar was in a state of constant repetition of the stories; in other words, he was simply thinking about his own trauma. This is not the case in this scene, where Congo is forced to actually put himself in the position of the victims, something that he probably had actively, though unconsciously, avoided. The result is the acknowledgment of the Other's suffering, a knowledge that, from then on, will be impossible to hide. This scene provokes the following ones, both the one in which he shows his need for watching himself on the screen developing this reenactment, and the later scene in which he revisits the rooftop where he systematically murdered his victims, and eventually starts retching. From this perspective, this last, extremely impressive scene, would have taken place only because of the previous reenactment of the victim's role, and not because of the rest of the shooting of both the documentary and the amateur film. In other words, Anwar Congo -the traumatized perpetrator-was too focused on his own trauma to actually take into consideration the Other's trauma -his victims-, and the fact that he has acknowledged it through witness traumatization -the reenactment of the victim's role- has put him in a position where breaking the political taboo and recognizing the cultural trauma of the other social group is more likely to happen.

\section{A Possible Solution to the Vicious Cycle of Cultural Trauma-Political Taboo}

Throughout this paper, the connection between cultural trauma and political taboo has been described, in order to shed light on the issue. The intention of this analysis has been to study the possible reasons for the persistence of problematic sociopolitical contexts such as the one that exists in the Indonesian society from 1966, after the military coup and the mass assassinations had taken place. As it has been exposed, the fact that the perpetrators of those crimes remain in power, or belong to the social group benefited by those in power, might be a powerful reason to explain this situation. To reinforce this argumentation, I have developed an analysis of the social context based on the political taboos utilized to ensure the persistence of the official version of the recent past, given by the government. This mythic tale of the people who saved the country from the communists reinterprets the past in a way that it turns killers into heroes. As a result, the cultural trauma inflicted by the killers cannot be healed, since 
the people who suffered such acts do not receive public recognition as victims, and since they themselves cannot publicly speak about their version of the past, because they fear the consequences of questioning the official narrative. Since healing trauma needs the traumatized person to speak about the traumatic event, a listener who actively engages with the story, and the public recognition of their status of victims, this social group cannot depart from the experience and, as a result, cultural trauma remains unsolved.

After having reflected on this matter, I have turned my attention toward the perpetrators themselves, in an attempt to understand their behavior. The central question here has been "why do they not recognize the Other as a victim?". In order to answer it, I have highlighted the importance of another type of trauma, which is perpetrator trauma. This approach offers the chance for the criminal to also have been traumatized by the event, in this case, one that they themselves have actively provoked. This approach is based on questioning the moralistic attitude usually applied to the concept of trauma, one which denies the mere possibility of this type of trauma, or even denies the opportunity for these people to heal from it, as some sort of punishment. I consider that this is not only morally questionable, but also, and more importantly, one of the reasons why certain cases of cultural trauma might not be in the process of healing. As I have exposed, the traumatized person is normally more invested in their own trauma, a situation that can easily prevent them from taking the Other's trauma into consideration. This might be the case for the Indonesian perpetrators. At the same time, if there is no place for them to earn some self-redemption, they will be less inclined toward recognizing the status of the Other. The reasoning is not only simple, but actually very understandable: if recognizing this situation means becoming a monster, deprived of any kind of humaneness, it will be very unlikely that the perpetrators will take this step, especially if we take into consideration that they control, or are sheltered by, the State's official narrative of the past. This can explain why none of the perpetrators interviewed in The Look of Silence are any close to recognizing that their actions were cruel and questionable, and legitimizing Adi's feelings as a victim of cultural trauma.

All these arguments are present in the case of Anwar Congo, the protagonist of The Act of Killing, and one of the mass killings perpetrators. Nevertheless, he is in a different psychological state than the rest of the perpetrators -or, at least, that is the interpretation that the documentary offers-, since he is actually suffering from post-traumatic stress disorder (PTSD). He oscillates from the need to express his suffering to negating the status of victims of the ones he killed. $\mathrm{He}$ needs to express what happened because, deep inside, he knows that what he did 
was atrocious, but accepting the consequences of this situation -becoming an inhumane monster- is a weight too heavy to handle, and, as a result, he eventually finishes his thoughts with the negation of the situation.

As I have exposed, the crucial change in his behavior takes place once he allows empathy to play a bigger role in his circular thoughts. Through the reenactment of a victim's role, he allows a process of identification that provokes the development of witness traumatization. Through acknowledging the Other's trauma, negating the situation becomes impossible, and the consequence is the intensification of the PTSD, as the documentary shows in the already mentioned scene where he starts retching.

At this point, it is crucial to understand the vision of this character offered by the film. The way the narrative arc of the protagonist is developed, and the fact that there is no redemptive catharsis for him, speaks about the moralistic vision of trauma mentioned before. Director Joshua Oppenheimer aligns with a vision of the issue that cancels any possibility for a perpetrator to be recognized as another victim of the conflict. This approach can be found in many narrative and mise-en-scène decisions throughout the two documentaries. On the one hand, it is fundamental to acknowledge the almost absolute lack of historical contextualization in both films-as it has been explained, it is reduced to a set of titles at the beginning of each film-, a fact that can easily allow a certain, or considerable, amount of manipulation. This situation is further reinforced by the narrative approach, which is based on testimonies and emotions, and not on a rigorous investigation based on facts, documents, and proofs. At the same time, it is easily arguable that Oppenheimer takes advantage of the naivety of the perpetrators, who are far from aware of how poorly they will be depicted on screen, once their testimonies have been recorded, a situation that is enhanced by a constant sense of frivolity in every action they develop in front of the camera -the appearance of the films would be considerably different if they would have followed the narrative model of the talking heads, with the conversations or testimonies recorded with a solemn atmosphere in a studio, for example-. Finally, the terrifying scene in which Anwar Congo starts retching is especially cruel because of how long it is -it is very unlikely that one of his victims would have been shown on screen for such a long time in such a pathetic situation-. In the end, the director is taking advantage of these characters to encourage the reenactments of their crimes, a situation in which Anwar Congo participates because he "seems to be avidly seeking solace for his trauma through the reenactment of his crimes," a scenario that never takes place, since "the film firmly denies him such relief by exposing his and his comrades' ill-directed sexual drives 
and by piling up evidence to the enormity of their acts through their very reenactments" (Nagib, 2016, p. 229). The way the scene is shot, with the protagonist appearing all pathetic, speaks of the moralistic approach of the project, which is directly linked with the very long silences and the judgemental gazes with which Adi punishes the perpetrators in The Look of Silence. In both cases, the films offer no possible redemption or ease to the situation of the perpetrators, and, as it has been argued, this might actually be part of the problem that provokes the unsolvable cultural trauma.

Delving into the total lack of context of Indonesia's recent past, Mohamed points out that "after a mention that the killings were carried out under the auspices of the military in the film's opening text, the military, and the state more generally, is absent from explanations of the crimes themselves" (2015, p. 1206). She opens the possibility of him having been actually manipulated by the State: "Was Anwar Congo indoctrinated? Desperate for money or power in a system that oppressed him or people like him? Coerced by a superior? Forced?" (Mohamed, 2015, p. 1198), and even though she points out that the documentary never addresses this possibility, in the end, she concludes that " $[w]$ hen Anwar Congo killed one thousand people, he was a free man; he wanted to kill and chose to kill on his own," because he claims that the government had no responsibility on his decisions, that he just "had to do it," as he himself argues (Mohamed, 2015, p. 1206). At this point, I am inclined to consider that this situation is too suspicious to just accept it as it is. Even though there is no proof for confirming either of the possible versions -just testimonies-, it is hard to believe that the government did not ensure that the perpetrators followed its doctrine and acted as the rulers wanted them to. The almost total absence of testimonies from the past and present governments expands this suspicion. Nevertheless, there is one testimony, given by Syamsul Arifin, the governor of North Sumatra, that can help in understanding the relationship between the State and the perpetrators that was developed during the mass killings: "Communists will never be accepted here, because we have so many gangsters, and that's a good thing. The word 'gangster' [preman] comes from English: 'free men'. Thugs want the freedom to do things, even if they're wrong, but if we know how to work with them, all we have to do is direct them" (emphasis is mine). If this were to be true, the rulers would have manipulated the perpetrators into making them believe that what they were doing was right and necessary, no matter the cost. This is the logic that I suspect might be behind the case of Anwar Congo, who, following the logic of the political taboo, could have unconsciously erased these manipulations -or not even have been conscious of them- to allow the official narrative to remain unquestionable, and thus giving him relief from his own traumatic past. 
This interpretation would be further reinforced if we take into consideration the testimony of another perpetrator offered in The Look of Silence, namely, Adi's uncle. He was one of the guards of a prison where people accused of being communists were held before being executed: "I was ordered to guard the prisoners. I didn't know what happened after they took the prisoners away. I was just a guard." As the audience discovers during the conversation, Ramli, Adi's brother and the nephew of this perpetrator, was held captive in this very prison. When Adi asks him if he could have done something to save his life, he answers: "No, I couldn't. Komando Aksi was under army command, and so was I. I was ordered to guard the prison, so I did. [...] If I refused, I'd be accused too. Better just to follow orders." (emphasis is mine). In this testimony, we can see the level of implication of the State, through the army. According to the vision of this perpetrator, they were coerced to act as commanded, with the risk of being executed if they refused.

Taking this into consideration, it becomes even more believable that, instead of being just free men acting as they wished, they could be "perpetrators who operated within a systematic state-run killing machine," as Rithy Panh described in his documentary S21: The Khmer Rouge Killing Machine (2003) (Mohamed, 2015, p. 1198). Mohamed herself discards this possibility and opposes the actions of the Indonesian perpetrators to those of the Cambodian ones. Even though they still remain just testimonies, and no definite claims can be done, I am inclined to believe that the situation in the Indonesian genocide is more complex than it has been described, and I suspect that the State had a direct, strong implication in the decisions taken by the perpetrators. Controlling people in the shades, in an extra-official manner, is actually a very useful approach for the State, as another testimony offered in The Look of Silence suggests. In this case, the speaker is perpetrator Amir Hasan, who, when questioned about the level of support they received from the army, answers the following: "They waited at the road, with the truck. They didn't come down here. They called this 'the people's struggle'. So they kept their distance. If the army was seen doing this, the world would be angry. 'The army is killing the communists!'. So to protect their image, they made it look like the people exterminated the communists. But everybody knows the army was behind it." It seems very reasonable to extract the conclusion that there was actual political interest in implicating the perpetrators. By doing this, they not only did not receive bad press on an international scale, but also made sure that the people themselves supported them and would not question their actions in the future. The people themselves would be guilty of the crimes and, in this scenario, it is less likely to develop criticism, because it would actually be self-criticism, which is way less likely to take place. When 
blaming the government for the holocaust implies blaming oneself, it is easier to subconsciously erase memories or reinterpret the past in a way that one does not become an inhumane monster.

As a result, the final claim of this paper is the need for acknowledging the other side of the traumatic event and recognizing its relevance in fomenting the healing of the traumas created. The usual way to approach trauma is from a moralistic perspective, one that rejects any recognition of the perpetrator as a human being who suffers from the actions they did in the past, and instead depicts the perpetrator as an inhumane monster. As Mohamed claims, "recognizing perpetrator trauma erodes the all-too-common perception of perpetrators as cartoonish monsters by exposing their ordinariness and humanity" (2015, pp. 1157-58). At the same time, there should not be any doubt of this alternative approach being a condonation or relativization of the past events. In other words, "[ $t]$ he point is not to generate sympathy for a genocidaire," but to recognize them "as a person who chose to kill, and who now suffers because of it" (Mohamed, 2015, p. 1158).

As it has been exposed, this is necessary not only for the moral responsibility of treating humans as individuals with humaneness, but also to help in improving the situation of social groups affected by cultural trauma: "Acknowledging the reality of perpetrator trauma can improve reconciliation efforts in the aftermath of mass atrocity by exposing the need to rehabilitate perpetrators" (Mohamed, 2015 , p. 1157). As a matter of fact, by better understanding the truth behind these atrocious crimes, we can discover the real horror behind them, "that perpetrators are merely people, and that any other person could do the same" (Mohamed, 2015, p. 1158).

At this point, it is especially important to acknowledge our own share of responsibility in the situation, and the moral implications of our approach toward it. As Mohamed claims, treating the perpetrators as inhumane deviations from society can be beneficial for ourselves, as a way to reinforce our sense of community and humaneness: "To treat the perpetrator of mass atrocity as a unique monster can convince us all that we are different from them, that we share a common sense of decency and humanity, and that none of us could ever slide into that same darkness." In other words, keeping the perpetrators in this status is very tempting for us, because, in an indirect way, what their existence tells about us is that "we are different from those people, and that we are better" (Mohamed, 2015, pp. 1210-11). 


\section{Conclusion}

The Act of Killing and The Look of Silence are two documentaries filmed by Joshua Oppenheimer, which address the problematic sociopolitical context in nowadays Indonesia. After the 1965 military coup against the communist government, a mass killing of approximately one million citizens, accused of being communists, took place. The perpetrators of this holocaust remained in power or did not have to confront the law for the crimes committed, a situation that is still present in our time. As we can see in The Look of Silence, the perpetrators of the mass killings openly speak about them, even with pride in their voices. As it has been discussed, this attitude can be understood due to the official narrative that the dictatorship developed in order to explain the recent past. According to such narrative, the killers become mythic heroes who helped save the country from evil, which would presumably refer to the communists. In order to ensure that this discourse remained unquestionable, a set of political taboos were developed, leading to a situation where the victims are not only not recognized as such, but also afraid of speaking out about their traumatic past. Because, indeed, there is another version of the past: the one told by the victims of the mass killings. This is the vision offered in The Look of Silence, which could be understood as the other side of the coin of The Act of Killing. In order to explain the situation of this other social group, the concept of cultural trauma has been used. Cultural trauma is a very specific type of trauma that is attached to a concrete social group, with its own communal identity conditions and shapes. A very remarkable trait of this damage is the fact that members of this social group can become traumatized despite not having suffered the traumatic event themselves. As we can see through Adi, the protagonist of The Look of Silence, he has been traumatized by his brother's death even though he was not even born by the time the incident had taken place. As a result, the need for healing this type of trauma is fundamental, since, due to the characteristics of cultural trauma, it can be transmitted from generation to generation.

The process for the healing of cultural trauma -as with any type of traumaneeds the individual's recognition as a victim, through the presence of an active listener, who validates the feelings of the traumatized person. At the same time, it needs the public recognition of the State, so that the community is publicly acknowledged as a victim of past events. None of these things are happening in Indonesia, where victims are scared to talk about their feelings and experiences, and where the government, which shares the ideology imposed after the military coup, is not willing to take this step. In other words, as it has been argued, the political taboo is blocking the healing of cultural trauma. In this paper, the analysis of both sides and how one is blocking the evolution of the other has been exposed. However, 
when it comes to finding a possible solution for such a block, proposing that the ones in power change their minds and recognize the status of the victims did not seem to suffice, because, if after more than 50 years this has not happened, a change in the near future is unlikely to take place. Consequently, studying the behavior of the perpetrators, in order to find possible psychological blocks that prevent the status recognition of the victims, becomes relevant. To develop this analysis, Anwar Congo, the protagonist of The Act of Killing, has been chosen as the main subject of the study. Combining his traits, thoughts, fears, desires, and behavioral conduct, it can be concluded that he is a traumatized person, too, a conclusion that has led to study another type of trauma: perpetrator trauma.

By studying the past conflict from this perspective, the presence of a not-sousual idea when it comes to reflecting on trauma has emerged: the fact that the perpetrator can also suffer from the moral and psychological consequences of their own actions. Besides highlighting this thought, a reflection on the possible manipulation that these subjects could have experienced from the government has been made, a fact that would reinforce the status of victims of the perpetrators of the mass killings. Having established this possibility as a fact, some of the scenes where Anwar Congo exposes his post-traumatic stress disorder (PTSD) have been studied as well as the partial dramatic arc that the documentary proposes. In it, we see the perpetrator earning conscience of his own actions, therefore, recognizing the status of the victims he killed, a fact that does not lead to a cathartic redemption. At this point, it can be claimed that, even though Anwar Congo was traumatized by his past actions, he was not able to take this step further into acknowledging the status of the Other, and that this only happened due to the reenactment of a victim's role in the amateur film he was developing, along with other perpetrators. In this essay, we claim that being traumatized in a different sense, in this case, through witness traumatization, allowed a process of identification through which Congo was able to recognize something that he was unconsciously avoiding, due to guilt. The feelings of guilt and horror are key aspects of perpetrator trauma, since, even though perpetrators are traumatized, they are not willing to accept this situation or the fact that what they did was atrocious. Acknowledging that would mean understanding themselves as inhumane monsters. As a result, the fact that we tend to understand trauma in a moralistic sense, not allowing the perpetrator to be seen as a traumatized person, another type of victim, reinforces in them a pattern of rejection and denial, that prevents other traumas, such as cultural trauma in this case, from healing. By not accepting -both they themselves and the rest of the society- the perpetrator as a traumatized person, we are freezing them in a state where no social change is possible, especially in those cases where the perpetrators are in power. If we act in 
a way that allows the presence of empathy, it will be more likely to understand the Other's actions, fears, and pain -without the need to condone atrocious actions-, be this Other a victim or a perpetrator. As Cathy Caruth claims, trauma is not based "on what we simply know of each other, but on what we don't yet know of our own traumatic pasts" (1995, p. 11).

In conclusion, building a space where trauma is approached in a non-moralistic way can improve the chances of provoking a social change that would lead to a better life for the members of different social groups, as well as fomenting a more peaceful society. Because, as Mohamed claims, "[w] hen perpetrators and victims or survivors live beside each other, a gap in understanding or connection between the two may lead to continued victimization on an individual level or even to renewed conflict and mass violence at a collective level." In other words, it is not (only) about the perpetrator, but about peace, because " $[\mathrm{w}]$ ithout healing on the part of all affected individuals, reconciliation will necessarily suffer" (Mohamed, 2015, pp. 1204-05).

\section{References}

Alexander, J. C. (2004). "Toward a Theory of Cultural Trauma." In J. C. Alexander (Ed.) Cultural Trauma and Collective identity (pp. 1-30). University of California Press. https://doi.org/10.1525/9780520936768-002

Blanuša, N. (2017). "Trauma and Taboo: Forbidden Political Questions in Croatia." Croatian Political Science Review, 54 (1-2), 170-196. https://hrcak.srce.hr/183305

Caruth, C. (1995). "Trauma and experience: Introduction." In C. Caruth (Ed.) Trauma: Explorations in memory (pp. 3-12). The Johns Hopkins University Press.

Eyerman, R. (2004). "Cultural Trauma: Slavery and the Formation of African American Identity." In J. C. Alexander (Ed.) Cultural Trauma and Collective identity (pp. 60-111). University of California Press. https://doi.org/10.1525/9780520936768-004

Eyerman, R. (2019a). "Cultural Trauma, Collective Memory, and the Vietnam War." In Memory, Trauma, and Identity (pp. 143-165). Palgrave Macmillan. https://doi. org/10.1007/978-3-030-13507-2_7

Eyerman, R. (2019b). "Perpetrator Trauma and Collective Guilt: The My Lai Massacre." In Memory, Trauma, and Identity. (pp. 167-194). Palgrave Macmillan. https://doi. org/10.1007/978-3-030-13507-2_8

Giesen, B. (2004). "The trauma of perpetrators." In J. C. Alexander (Ed.) Cultural trauma and collective identity (pp. 112-154). University of California Press. https://doi. org/10.1525/9780520936768-00 $\underline{5}$

Krstic, I. (2002). "Re-thinking Serbia: A psychoanalytic reading of modern Serbian history and identity through popular culture." Other Voices 2.2 (pp. 1-28). http://www. othervoices.org/2.2/krstic/index.html 
Laub, D. (1992). "Bearing Witness, or the Vicissitudes of listening, and An Event without a Witness: Truth, Testimony and Survival." In S. Feldman and D. Laub (Eds.) Testimony: Crises of witnessing in literature, psychoanalysis, and history (pp. 57-74). Routledge. https://www.taylorfrancis.com/chapters/edit/10.4324/9780203700327-9/bearin

g-witness-vicissitudes-listening-dori-laub

Mohamed, S. (2015). "Of Monsters and Men: Perpetrator Trauma and Mass Atrocity." Columbia Law Review (pp. 1157-1216). https://www.jstor.org/stable/43582425

Nagib, L. (2016). "Regurgitated Bodies: Presenting and Representing Trauma in The Act of Killing." In Y. Tzioumakis, C. Molloy (Eds.) The Routledge Companion to Cinema and Politics (pp. 240-252). Routledge. https://www.taylorfrancis.com/chapters/ edit/10.4324/9781315678863-33/regurgitated-bodies-presenting-representingtrauma-act-killing-I\%C3\%BAcia-nagib

Van den Braembussche, A. (1998). "The Silenced Past: On the Nature of Historical Taboos." In W. Wrzoska (Ed.) Swiat historii. Festschrift for Jerzy Topolski, (pp. 97-112). Historical Institute. https://researchportal.vub.be/en/publications/the-silencedpast-on-the-nature-of-historical-taboos 